\title{
THE EFFECT OF EL NINO AND LA NINA ON THE INTENSITY OF DETERMINING QIBLA DIRECTION
}

\author{
Muhammad Himmatur Riza', Nihayatul Minani ${ }^{2}$ \\ ${ }^{1}$ Institut Agama Islam Surakarta, ${ }^{2}$ Universitas Nahdlatul Ulama Al-Ghazali

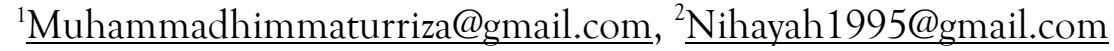

\begin{abstract}
:
On the basis of the annual pseudo motion of the Sun, there is a division of the seasons. In terms of seasons, there are several natural phenomena that can affect the seasons on earth, especially the natural phenomena of El Nino and La Nina. In Indonesia, El Nino can result in a longer dry season and La Nina can cause a longer rainy season. Thus, any research related to the influence of El Nino and La Nina is very important to do to determine whether these two natural phenomena affect the intensity of determining the direction of the Qibla. This research is included in the Library Research using qualitative research methods with a descriptive format. Data collection techniques used are documentation or literature and non-participant observation. Meanwhile, to analyze the data, the authors processed the field data obtained from the Class I Semarang Climatology Office to obtain the average climatological elements during the year of El Nino and La Nina, then the results were implemented in determining the direction of the Qibla. This study resulted in the finding that La Nina was sufficient to influence the implementation of determining the direction of the Qibla because at the time of La Nina the rain continued to occur throughout the year.

Keywords : El Nino, La Nina, Direction of Qibla
\end{abstract}

Abstrak :

Atas dasar gerak semu tahunan Matahari mengakibatkan adanya pembahgian musim. Dalam hal terkait dengan musim, terdapat beberapa fenomena alam alamiah yang dapat mempengaruhi musim di Bumi, terutama fenomena alam alamiah El Nino dan La Nina. Di Indonesia, El Nino dapat mengakibatkan kemarau lebih panjang dan La Nina dapat menyebabkan musim hujan yang lebih panjang. Sehingga, penelitian terkait pengaruh EL Nino dan La Nina sangat penting dilakukan untuk mengetahui apakah kedua fenomena alam alamiah tersebut mempengaruhi intensitas penentuan arah kiblat. Penelitian ini termasuk 
dalam penelitian Library Reseacrh dengan menggunakan metode penelitian kualitatif dengan format deskriptif. Teknik pengumpulan data yang digunakan yaitu dokumentasi atau kepustakaan dan observasi nonparrtisipan. Sedangkan untuk menganalisis datanya, penulis melakukan pengolahan data lapangan yang diperoleh dari Kantor Klimatologi Klasi I Semarang untuk memperoleh rata-rata unsur klimatologi pada saat tahun terjadinya El Nino dan La Nina, kemudian hasilnya diimplementasikan dalam penentuan arah kiblat. Penelitian ini menghasilkan temuan bahwa La Nina cukup mempengaruhi implementasi penentuan arah kiblat karena pada saat tahun terjadinya La Nina hujan terus terjadi sepanjang tahun.

Kata Kunci: El Nino, La Nina, Arah Kiblat

\section{A. Introduction}

As an archipelago located between the Indian Ocean and the Pacific Ocean, rainfall in Indonesia is strongly influenced by changes in sea surface temperature around it. When there is an increase in sea surface temperature in the Central and Eastern Pacific Ocean around the equator known as El Nino, this is related to a decrease in rainfall in Indonesia. Likewise, when there is a decrease in sea surface temperature in the Middle and East Pacific Ocean around the equator or better known as La Nina, it is associated with increased rainfall in Indonesia ${ }^{1}$.

Several global phenomena that affect Indonesia's climate, are: El Nino, La Nina, Dipole Mode ${ }^{2}$ and Madden Julian Oscillation (MJO), in addition to regional phenomena such as: the Asia-Australia monsoon circulation ${ }^{3}$, the Inter Tropical Convergence Zone (ITCZ) ${ }^{4}$ meeting area as well as sea level temperature conditions around the territory of Indonesia 5 .

This global phenomenon seems to be one of the weaknesses of determining the direction of the Qibla, because determining the direction of the Qibla really requires

\footnotetext{
${ }^{1}$ Ardila Yananto dan Saraswati Dewi, “Analisis Kejadian El Nino Tahun 2015 Dan Pengaruhnya Terhadap Peningkatan Titik Api Di Wilayah Sumatera dan Kalimantan,” Jurnal Sains \& Teknologi Modifikasi Cuaca 17, no. 1 (2016): 11-19.

${ }^{2}$ Dipole Mode is a sea-atmosphere interaction phenomenon in the Indian Ocean which is calculated based on the difference in value between the sea surface temperature anomaly in the waters of the East African coast and the waters to the west of Sumatra. See the annual report by the Meteorology, Climatology and Geophysics Agency, "2015 Dry Season Forecast in Indonesia” (Jakarta, 2015), p.2. 2015)

${ }^{3}$ Meteorology, Climatology and Geophysics Agency, "2015 Dry Season Forecast in Indonesia” (Jakarta,

${ }^{4}$ Meteorology, Climatology and Geophysics Agency

${ }^{5}$ Tumiar Katarina Manik, "Klimatologi Dasar", (Yogyakarta: Graha Ilmu, 2014), p. 128.
} 
sunlight. For example, in the year of El Nino and La Nina ${ }^{6}$. Whereas Indonesia's geographical location, which is between the Asian Continent and the Australian Continent and between the Pacific and Indian Oceans, has caused Indonesia to receive a significant impact due to the El Nino and La Nina phenomena, although not comprehensive?

El Nino is scientifically defined as a global phenomenon of the interaction between the sea and the atmosphere, which is characterized by an increase in Sea Surface Temperature (SST) around the Central and Eastern Pacific along the equator of its average value. In normal years, the SST in the North and Northeast Australia is $\geq 28^{\circ} \mathrm{C}$ while the SST in the Pacific Ocean around South America is worth $\pm 20^{\circ} \mathrm{C}$. Under that normal conditions, equatorial winds blow westward to help the convection process in the Western Pacific and subsidence in the East Pacific ${ }^{8}$.

The effect of the El Nino / IOD (+) phenomenon is a decrease in the amount of annual and seasonal rainfall, especially June - July - August (JJA) and September October - November (SON) for both monsunal and equatorial rainfall types. Otherwise, La Nina and IOD (-) cause an increase in the amount of rainfall. The impact of the El Nino phenomenon for most parts of Indonesia is always associated with drought due to reduced rainfall intensity 9 .

The existence of the Sun in the method of determining the direction of the Qibla is very important, both determining the direction of the Qibla using the theodolite with the Sun as a reference (Natural Scientific Method) and determining the direction of the Qibla using the Sun whose light will cause shadows (Natural Scientific Method). El Nino and La Nina give the impact of climate anomalies which cause a long dry season or long rainy season. So that the existence of climate anomalies during the

\footnotetext{
${ }^{6}$ Isniyatin Faizah, "Studi Analisis Penanggalan Jawa Pranata Mangsa Dalam Perspektif Astronomi" (IAIN Walisongo Semarang, 2013), p.58.

7 "Fenomena Alam El Nino," n.d., ttp://idkf.bogor.net/yuesbi/eDU.KU/edukasi.net/Fenomena.Alam/El Nino/materi4.html. Retrieved on Tuesday, 23 April 2021, $12: 47$ Western Indonesian Time

${ }^{8}$ Tongkukut, S.H.J. (2011), "El Nino dan Pengaruhnya Terhadap Curah Hujan di Manado Sulawesi Utara" Jurnal Ilmiah Sains, 11(1), 102-108.

${ }^{9}$ S.W.B. Harijono B. Tjasyono, A. Lubis, I. Juaeni, Ruminta, "Dampak Variasi Temperatur Samudera Pasifik Dan Hindia Ekuatorial Terhadap Curah Hujan Di Indonesia”, Jurnal Sains Dirgantara 5, no. 2 (2008): 1-13.
} 
year of El Nino and La Nina, can be an obstacle in determining the direction of the Qibla. Because, during the rainy season, the sun rarely appears due to overcast or even rain. This becomes an obstacle in determining the direction of the Qibla because this determination cannot be separated from the existence of the Sun.

There are several studies related to the effects of El Nino and La Nina that have been previously studied as follows. Iriwi L.S Sinon in Identification of The Effect of El Nino and La Nina on Annual Rainfall Variation in Biak Numfor District, Papua Province. The findings of this study are that El Nino and La Nina have no significant effect on rainfall in the area. This is evidenced during a period of 48 years, there were about 23 El Nino events, only 4 times which had an effect on the intensity of rain in the area and out of 23 La Nina events only 1 time had an effect on rainfall ${ }^{10}$. Farras Nabilah et.al, entitled Analysis of the Effect of El Nino and La Nina Phenomenon on Rain in 1998 - 2016 Using Oni (Oceanic Nino Index) Indicators (Case Study: West Java Province) ${ }^{11}$, the findings of this study are a map of SST distribution and rainfall simultaneously. seasonality to determine the effect of the El Nino and La Nina phenomena in the West Java region. Gabriel Yedaya Immanuel Ryadi et.al, entitled The Influence of El Nino and La Nina Phenomenons on Rain Flow Distribution and Land Dry Levels in Bali Island. The results of this study indicate the effect of El Nino and La Nina on the distribution of rainfall and sea surface temperature has a unidirectional relationship, which is if the sea surface temperature is high, the rainfall is also high. In addition, this study concludes that there is an effect of changes in the ONI index as an indicator of El Nino and La Nina on changes in the area of drought with a large effect of $86 \%{ }^{12}$.

Based on this, the author examines the effect of El Nino and La Nina on the intensity of determining the direction of the Qibla.

\footnotetext{
${ }^{10}$ iriwi L.S Sinon, "Identifikasi Pengaruh El Nino Dan La Nina Terhadap Variasi Curah Hujan Tahunan Di Kabupaten Biak Numfor Provinsi Papua,” presented in Seminar Nasional Pendidikan (Banjarmasin, 2018), p.243.

${ }^{11}$ Farras Nabilah, Yudo Prasetyo, and Abdi Sukmono, "Analisis Pengaruh Fenomena El Nino Dan La Nina Terhadap Curah Hujan Tahun 1998 - 2016 Menggunakan Indikator Oni (Oceanic Nino Index) (Studi Kasus : Provinsi Jawa Barat)," Jurnal Geodesi Undip $6 \quad$ (November 15, 2017), p. 411, https://ejournal3.undip.ac.id/index.php/geodesi/article/view/18170.

12 gabriel Yedaya Immanuel Ryadi, Abdi Sukmono, And Bandi Sasmito, "Pengaruh Fenomena El Nino Dan La Nina Pada Persebaran Curah Hujan Dan Tingkat Kekeringan Lahan Di Pulau Bali," Jurnal Geodesi Undip 8 (October 7, 2019), p.48 https://ejournal3.undip.ac.id/index.php/geodesi/article/view/25143.
} 


\section{B. Research Methods}

This research is included in the library research ${ }^{13}$ using qualitative research methods with a descriptive format ${ }^{14}$. The data collection techniques used are documentation or literature and non-participant observation ${ }^{15}$. The primary data used in this study were climatological element data during the year of El Nino and La Nina which were obtained from the Class I Semarang Climatology Office in the form of numerical data and secondary data from the authors obtained from other sources related to the research, such as: astronomy, climatology, El Nino and La Nina books and related web. Meanwhile, to analyze the data, the authors processed the field data obtained from the Class I Semarang Climatology Office to obtain the average climatological elements during the year of El Nino and La Nina, then the results were implemented in determining the direction of the Qibla.

\section{Discussions and Results}

\section{C.1. Definition of Qibla Direction and It's Determination Methods}

Direction in Arabic is called jihah, syathrah or simt which means the area or point where an object is facing or moving, can also be interpreted as the location of a point in space relative to another ${ }^{16}$. While Qibla is taken from the word قبل which is a form of mashdar (derivation) of the word قبل-قيبل-قبلة (qabalayaqbilu-qiblatan) means facing ${ }^{17}$. These two words have the same meaning, their origin is the situation of the person who comes to face them, then they are

${ }^{13}$ Bungaran Antonius Simanjuntak dan Soedjito Sosrodihardjo, "Metode Penelitian Sosial", (Jakarta: Yayasan Pustaka Obor Indonesia, 2009), p. 8.

${ }^{14}$ Burhan Bungin, "Metodologi Penelitian Kuantitatif, Komunikasi, Ekonomi Dan Kebijakan Publik Serta Ilmu - Ilmu Sosial Lainnya," (Jakarta: Kencana, 2005), p. 43-44.

15 The non-participant observation referred to is that the researcher does not go directly to collect data one by one, but uses existing data which is then double-checked. See James A. Black \& Dean J. and Champion, "Metode Dan Masalah Penelitian Sosial", translated by E. Koswara, et.al, (Bandung: Refika Aditama, 2009), p. 289.

${ }^{16}$ Roy Holland, "Kamus Matematika ( A Dictionary of Mathematics)", translated by Naipospos Hutauruk (Jakarta: Erlangga, 1999), p.4.

${ }^{17}$ Ahsin Dinal Mustafa, "Qibla Direction Trough Ulama's Fatwa: Comparative Study between Qibla Direction Fatwa of Indonesian Ulama Council and Dar Al Ifta Al Misriyyah,” Al-Hilal: Journal of Islamic Astronomy 1 (2019), p.111. 
defined specifically for the direction in which every mushalli (praying person) must face $\operatorname{him}^{18}$.

In terms of the Qibla direction is the closest direction to the Ka'ba (alMasjid al-Haram) through a great circle of the earth, this circle is a circle of the globe through the center of the Ka'bah and the opposite point of the center of the Ka'bah itself so that it is automatically cuts straight the center of the earth, this circle is often referred to as the Qibla circle ${ }^{19}$.

Facing the Qibla during prayer is not without any legal bases, these legal bases are as follows:

1. The Holy Quran surah al-Baqarah (The Cow) verses 149-150

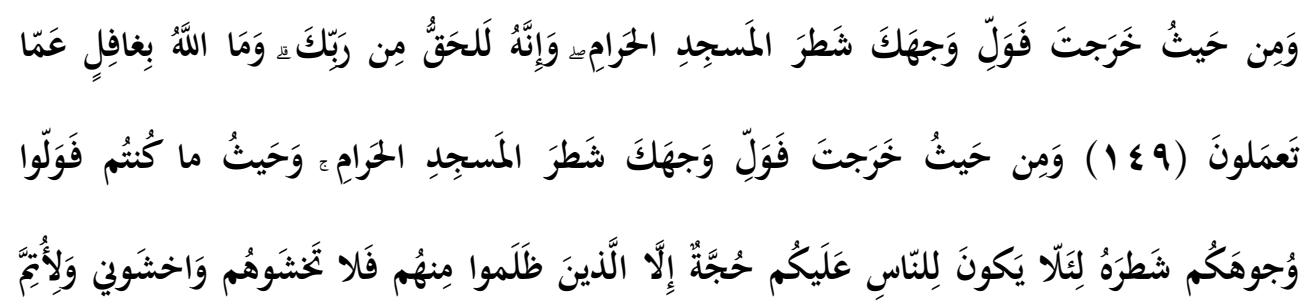

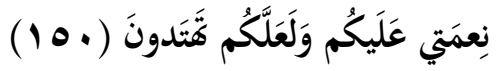

"Whencesoever you may go out, turn your face towards the Holy Mosque. Indeed it is the truth from your Lord, and Allah is not oblivious of what you do. And whencesoever you may go out, turn your face towards the Holy Mosque, and wherever you may be, turn your faces towards it, so that the people may have no argument against you, neither those of them who are wrongdoers. 1 So do not fear them, but fear Me, that I may complete My blessing on you and so that you may be guided"20.

2. Hadith Narrated By Imam Moslem

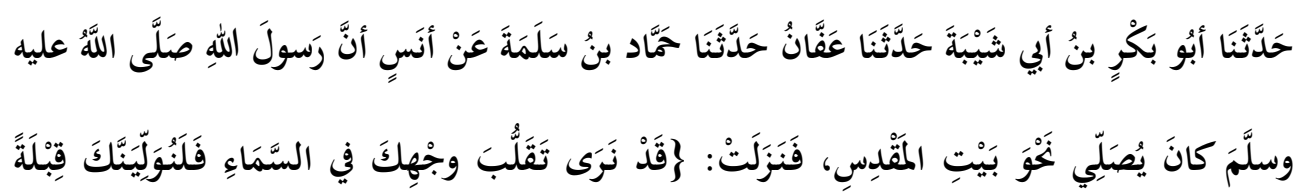

${ }^{18}$ A. Kadir, "Quantum Ta'lim Hisab-Rukyat : Cara Cepat Pintar Kalkulasi Arah Kiblat Syar'i, Waktu-Waktu Shalat Abadi, Plus Awal Bulan 8 Gerhana Sistem 45 Menit ", (Semarang: Fatawa Publishing, 2014), p. 39-40.

19 Slamet Hambali, "Metode Pengukuran Arah Kiblat yang Dikembangkan Di Pon-Pes Al-Hikmah II Benda Sirampak Kabupaten Brebes" (Semarang: IAIN Walisongo, 2010), p.14.

${ }^{20}$ Ministry of Religious Affairs of The Republic of Indonesia," Al-Quran dan Terjemahnya", (Jakarta: CV. Darus Sunnah, 2007), p. 24. 


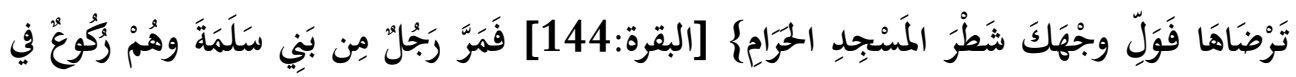

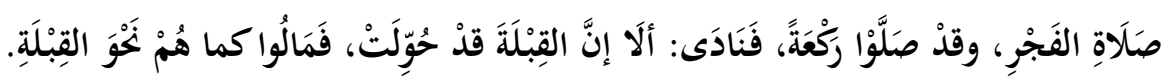

"Abu Bakr bin Abi Syaibah told us, Affan told us, Hammad bin Salamah told us, from Thabit from Anas:" That the Messenger of Allah (one day) was praying facing Baitulmakdis, then came down the verse. "Indeed, I see that your face often looks up to the sky, so we really turn your face to the Qibla that you want. Turn your face towards the Masjidilharam ". Then a person from Bani Salamah was traveling, and met a group of friends bowing to prayer at dawn. Then he exclaimed, "Indeed the qibla has changed." Then they turned like a group of prophets, namely towards the Qibla." (The Hadith Narrated by Imam Moslem) ${ }^{21}$.

There are several methods of determining the Qibla direction are developing, according to Izzuddin, the methods of determining the Qibla direction is classified based on the typology of its application as follows ${ }^{22}$ :

1. Natural Method

Natural phenomena in history are often used as markers of something ${ }^{23}$, such as a marker for the direction of the Qibla ${ }^{24}$. The natural method of determining the Qibla direction refers to natural phenomena. The method which is included to this this natural method such as using the constellations of the stars.

\section{Natural Scientific Method}

This method is based on natural events or phenomena which are then used to determine the Qibla direction with calculations. Some of methods included in this method are using the compass, Istiwa' Pole, Protractor, Qibla

\footnotetext{
${ }^{21}$ Abu al-Husain Muslim ibn Hajjaj ibn Muslim al-Qusyairi al-Naisabury, "Shahih Muslim" (Beirut: Dar alKutub al-'Ilmiyyah, n.d.), p. 423.

22 Ahmad Izzuddin, "Kajian terhadap Metode-Metode Penentuan Arah Kiblat dan Akurasinya" (Jakarta: Kementerian Agama RI, Direktorat Jenderal Pendidikan Islam, Direktorat Pendidikan Tinggi Islam, 2012), p. 146-147.

${ }^{23}$ M Ihtirozun Ni'am, “Tsuroyya's Star as A Sign Of Pandemic's End (Critical Study of The End of a Pandemic From Hadith And Astronomical Perspective)," ELFALAKY 4, no. 2 (2020), p.132.

${ }^{24}$ M. Ihtirozun Ni'am, Nizma Nur Rahmi, and Fiki Burhanuddin, "Qibla Direction with The Constellation (Study on Determination of Qibla Direction with Gubug Penceng),” Al-Hilal: Journal of Islamic Astronomy 2 (2020): 35.
} 
Triangle, Astrolabe, Rubu' Mujayyab, Mizwala Qibla Finder, Istiwa'aini, Qibla

Laser, Qibla Ruller, Qibla Locator, Theodolite and Al-Murobba ${ }^{125}$.

3. Scientific Natural Method

This method is a type of method that begins with scientific calculations and it is proven naturally in the field. The methods included in this classification are Rashdul Qibla and Equatorial Sundial.

\section{C.2. Understanding El Nino and La Nina}

El Nino is an ocean current or wind that periodically blows between 5 and 10 years, usually near the west coast of South America to Central America. This current has a temperature exceeding the ambient temperature. This current usually occurs in December and has a negative impact on tropical American countries such as Honduras and Mexico ${ }^{26}$.

El Nino is often called the warm event in The Central and Eastern Equatorial Pacific Oceans. El Nino will occur if the warm pool in the Pacific Ocean region - the equator - moves to the east, which causes SST in the East Pacific Ocean to rise by an average of $0.5^{\circ} \mathrm{C}-2^{\circ} \mathrm{C}^{27}$.

El Nino is grouped into four, namely; Weak El Nino, Moderate El Nino, Strong El Nino and Very Strong El Nino ${ }^{28}$. The division of El Nino types is based on the Oceanic Nino Index (ONI) : Weak El Nino, which is if the deviation of SST in The Equatorial Pacific is $+0.5^{\circ} \mathrm{C}$ to $+0.9^{\circ} \mathrm{C}$, Moderate El Nino, if the deviation of SST in The Equatorial Pacific is $+1.0^{\circ} \mathrm{C}$ to $+1.4^{\circ} \mathrm{C}$, Strong El Nino, if the deviation of SST in the equatorial Pacific is $+1.5^{\circ} \mathrm{C}$ to $+1.9^{\circ} \mathrm{C}$, and Very Strong El Nino, if the deviation of SST in the equatorial Pacific is $\geq+2.0^{\circ} \mathrm{C}^{29}$. All

\footnotetext{
${ }^{25}$ M. Ihtirozun Ni’am, "Al-Murobba': Inovasi Alat Falak Multifungsi", (Semarang: Mutiara Aksara, 2020), p.26.

${ }^{26}$ Hasan Basri Jumin, "Agroekologi: Suatu Pendekatan Fisiologis", (Jakarta: Raja Grafindo Persada, 2002), p.59.

${ }^{27}$ Moch. Sodiq, Pemanasan Global: Dampak Terhadap Kehidupan Manusia Dan Upaya Penanggulangannya" (Yogyakarta: Graha Ilmu, 2013), p.5.

${ }^{28}$ Sodiq, Pemanasan Global: Dampak Terhadap Kehidupan Manusia Dan Upaya Penanggulangannya.

${ }^{29}$ Jan Null, "El Nino and La Nina Years and Intensities," n.d., http://ggweather.com/enso/oni.htm. Retrieved on Tuesday, 23 February 2021, 09:03 Western Indonesian Time.
} 
El Nino deviation criteria in the Pacific last a minimum of 3 consecutive months ${ }^{30}$.

The flow of the process for the occurrence of an El Nino is as follows ${ }^{31}$ :

1. The Central and Eastern Pacific waters are heating up in temperatures.

The process of the occurrence of El Nino begins due to an increase in temperature in The Eastern and Central Pacific waters. This condition causes an increase in humidity temperature in the atmosphere over the waters of The Eastern and Central Pacific.

2. Cloud formation

After the heating up of the temperature in The Central and Eastern Pacific waters which causes humidity in the upper atmosphere, then this event encourages the formation of clouds and will increase the rainfall in the region.

The global phenomenon that sometimes dries up El Nino is La Nina, which is a negative SST anomaly in The Central Pacific Equator that becomes cooler than average ${ }^{32}$. Similar to El Nino, La Nina is also divided into four based on the intensity of the sea surface temperature anomaly (SST). This El Nino division is also based on the Oceanic Nino Index (ONI): Weak La Nina, which is if the deviation of SST in The Equatorial Pacific is $-0.5^{\circ} \mathrm{C}$ to $-0.9^{\circ} \mathrm{C}$, Moderate La Nina, if the deviation of SST in The Equatorial Pacific is $-1.0^{\circ} \mathrm{C}$ to $-1.4^{\circ} \mathrm{C}$, Strong La Nina, if the deviation of SST in The Equatorial Pacific $-1.5^{\circ} \mathrm{C}$ to $-1.9^{\circ} \mathrm{C}$, and Very Strong La Nina, if the deviation of SST in The Equatorial Pacific is $\geq$ $2.0^{\circ} \mathrm{C}^{33}$. All criteria for deviation of La Nina in the Pacific last at least 3 consecutive months ${ }^{34}$.

\footnotetext{
30 "Fenomena Alam El Nino," n.d., http://idkf.bogor.net/yuesbi/eDU.KU/edukasi.net/Fenomena.Alam/ElNino/materi2. html.

Retrieved on Tuesday, 23 February 2021, 20:31 Western Indonesian Time.

31 "Fenomena Alam Proses Terjadinya El Nino Dan La Nina," ilmugeografi.com, n.d. retrieved on Tuesday, 23 February 2021, 16:48 Western Indonesian Time.

32 Sodiq, "Pemanasan Global: Dampak Terhadap Kehidupan Manusia dan Upaya Penanggulangannya", p. 6.

33 Null, "El Nino and La Nina Years and Intensities." n.d., http://ggweather.com/enso/oni.html. Retrieved on Tuesday, 23 February 2021, 09:03 Western Indonesian Time.

34 "Fenomena Alam El Nino.",

http://idkf.bogor.net/yuesbi/eDU.KU/edukasi.net/Fenomena.Alam/ElNino/m ateri2.html. Retrieved on Tuesday, 23 February 2021, 20:31 Western Indonesian Time.
} 
The flow of La Nina occorence is as follows ${ }^{35}$ :

1. The winds in The Pacific Ocean are strong

La Nina is referred to as the phenomenon of decreasing temperature on the surface of The Eastern Pacific Ocean waters. At such times the east trade winds blow and strengthen along the Pacific Ocean.

2. Warm water masses carried toward the Western Pacific

Due to the strong winds blowing along the Pacific Ocean, more warm water masses will be carried towards the West Pacific.

3. The occurrence of Upwelling

The mass of warm water that is carried to the Western Pacific in greater numbers causes the cold water mass in the Eastern Pacific to move upwards and then replace the warm water mass that migrates to the West Pacific. This condition is called upwelling. Due to the mass change, the temperature at sea level has decreased when compared to normal conditions.

El Nino and La Nina can be identified through four regions, namely: Region Nino 3.4, Region Nino 3, Region Nino 4 and Region Nino 1+2. In this study, the author uses Region Nino 3.4 or also called Oceanic Nino Index (ONI), which detects SST anomalies in the Pacific Ocean which experience hot and cold phases with the condition that the temperature exceeds the normal limit $+/-0.5^{\circ} \mathrm{C}$ last for three consecutive months ${ }^{36}$.

\section{C.3. El Nino and La Nina impacts}

During El Nino event, the SST of The Eastern Pacific increases. However, this situation is inversely proportional to SST around Indonesia. Low temperatures and increased air pressure occur in the seas around Indonesia. The

35 "Fenomena Alam Proses Terjadinya El Nino dan La Nina”, n.d., http://ilmugeografi.com/fenomenaalam/proses-terjadinya-el-ninodan-la-nina. Retrieved on Tuesday, 23 February 202, 16:48 Western Indonesian Time.

36 "Equatorial Pacific Sea Surface Temperatures," National Oceanic and Atmospheric Administration, n.d., https://www. ncdc. noaa.gov/ teleconnections/enso/indicators/sst.php. Retrieved on Tuesday, 23 February 2021, 12:22 Western Indonesian Time.

Al-Hilal: Journal of Islamic Astronomy, Vol. 3, No. 1, 2021

p-ISSN : 2775-1236 ; e-ISSN : 2775-2119 
cooling of the warm sea surface around Indonesia waters due to the attraction of the entire air mass to the eastern part of The Pacific ${ }^{37}$.

The air tends to move down from higher air pressure to areas with lower air pressure. This means that the winds above sea surface in The Western Pacific will move to the east and bring air vapor to the west rotating to the east, causing Indonesia to occur drought ${ }^{38}$.

The El Nino phenomenon causes less rainfall in most parts of Indonesia. This phenomenon has a varying effect depending on the intensity of the El Nino that occurs. However, due to Indonesia's geography, which is known as a maritime continent, not all of Indonesia's territory was developed by the El Nino phenomenon ${ }^{39}$. El Nino has a low effect on annual rainfall in parts of Indonesia. This low influence includes large parts of Indonesia, namely in Kalimantan, parts of northern Java, Nusa Tenggara Islands and parts of Papua.

The occurrence of the La Nina phenomenon when the SST in Indonesian waters warms up will result in increased rainfall in Indonesia ${ }^{40}$. La Nina has a low impact on rainfall in parts of Indonesia, including: parts of Sumatra, Kalimantan, Java, Sulawesi, Papua, the Ternate Islands and the entire Nusa Tenggara region.

Compared to La Nina, El Nino has a bigger impact. The impact of El Nino and La Nina is significant in September - November (SON). El Nino has a significant impact in reducing rainfall on Java Island in the months of December February (DJF), but La Nina has a weak relationship. The effect of El Nino was negative during $\mathrm{SON}$ in all regions of Java, but in the DJF period El Nino was negative (negative means decreased rainfall) only covered the North Coast of Java. The South Coast of Java and the central part of Java (associated with mountains) actually occur positive anomalies. This is in contrast to the La Nina phenomenon,

37 “El Nino: Pengertian, Dampak, dan Proses Terjadinya," Pintarbiologi.Com, n.d., http://www.pintarbiologi.com/2015/08/el-nino-pengertian-dampakdanproses-terjadinya.html. Retrieved on Tuesday, 21 March 2021, 16:40 Western Indonesian Time.

38 "El Nino: Pengertian, Dampak, dan Proses Terjadinya."

39 "Fenomena Alam El Nino.", http://idkf.bogor.net/yuesbi/eDU.KU/edukasi.net/Fenomena.Alam/E 1Nino/materi4.html. Retrieved on Saturday, 15 April 2017, $12: 47$ Western Indonesian Time.

${ }^{40}$ Sodiq, "Pemanasan Global: Dampak Terhadap Kehidupan Manusia dan Upaya Penanggulangannya", p. 6. 
in which the central part of Java is mountainous, which shows a negative anomaly, while other regions give a positive value.

\section{C.4. Rainfall Anomaly}

Rain is a form of precipitation. Precipitation is the deposition of water from the atmosphere on the earth's surface in the form of liquid (rain drops) and solid (snow). In tropical areas such as Indonesia, precipitation is defined as rain because very rarely precipitation occurs in the form of falling ice grains. The amount of precipitation is recorded in inches or millimeters $(1$ inch $=25.4 \mathrm{~mm})$. The amount of rainfall of $1 \mathrm{~mm}$ indicates the height of rainwater covering the earth's surface as thick as $1 \mathrm{~mm}$, if the water does not seep into the ground or evaporate into the atmosphere ${ }^{41}$.

Rainfall has great variability in space and time. On a spatial scale, the variability is strongly influenced by geographic location, topography, wind direction and latitude. In the time scale, the variety of rainfall is divided into daily, monthly and yearly types. Variations in daily rainfall are more influenced by local factors, monthly variations are influenced by land and sea breezes, convection activity, direction of surface air flow and variations in the distribution of land and oceans. Meanwhile, the variation in annual rainfall is influenced by the behavior of the global atmosphere, tropical cyclones, and others. In general, rainfall in Indonesia is dominated by the influence of several phenomena such as the Asian-Australian monsoon system, El Nino / La Nina, the east-west circulation, the north-south circulation, and several circulations due to local factors ${ }^{42}$.

Rainfall Anomaly During January 2016

Rainfall Anomaly During February 2016

${ }^{41}$ Ardila Yananto dan Rini Mariana Sibarani, "ANALISIS KEJADIAN EL NINO DAN PENGARUHNYA TERHADAP INTENSITAS CURAH HUJAN DI WILAYAH JABODETABEK (Studi Kasus: Periode Puncak Musim Hujan Tahun 2015/2016)," Jurnal Sains \& Teknologi Modifikasi Cuaca 17, no. 2 (2016), p.65-73.

${ }^{42}$ R. Prasetya, "Analisis Curah Hujan Akibat Siklon Tropis Nangka, Parma dan Nida di Sulawesi Utara" (Universitas Sam Ratulangi Manado, 2011).

Al-Hilal: Journal of Islamic Astronomy, Vol. 3, No. 1, 2021

p-ISSN : 2775-1236 ; e-ISSN : 2775-2119 

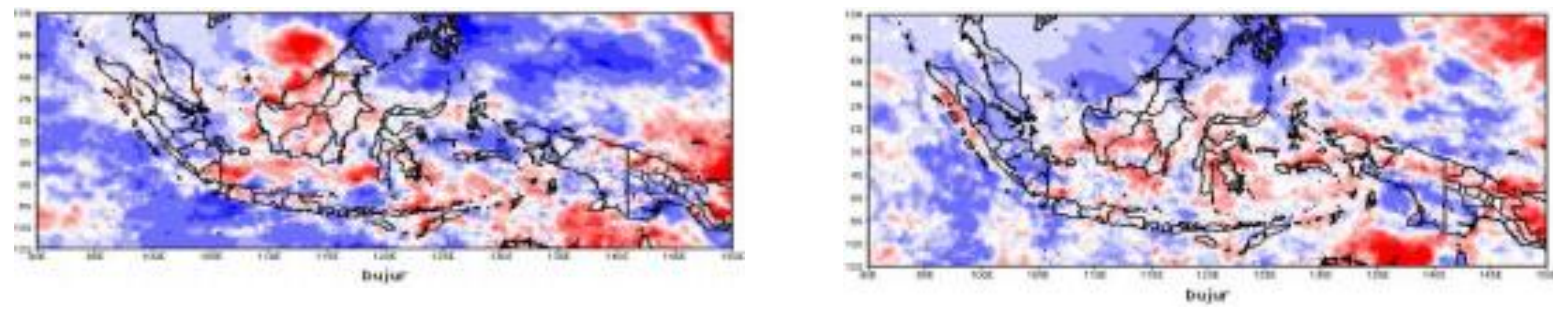

Rainfall Anomaly During March 2016

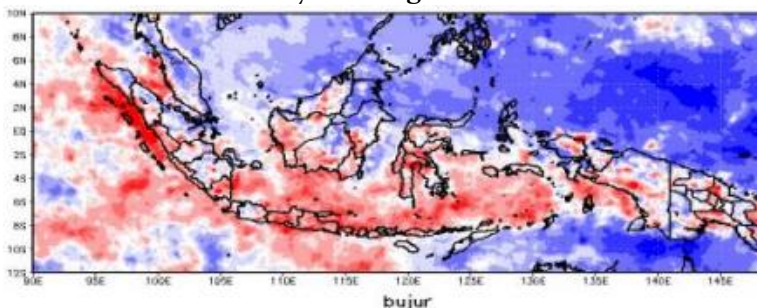

Rainfall Anomaly During May 2016

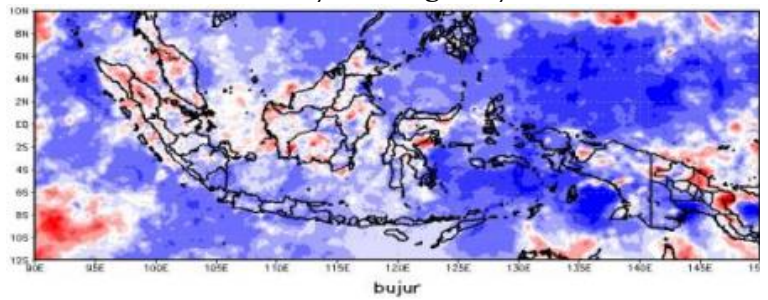

Rainfall Anomaly During July 2016

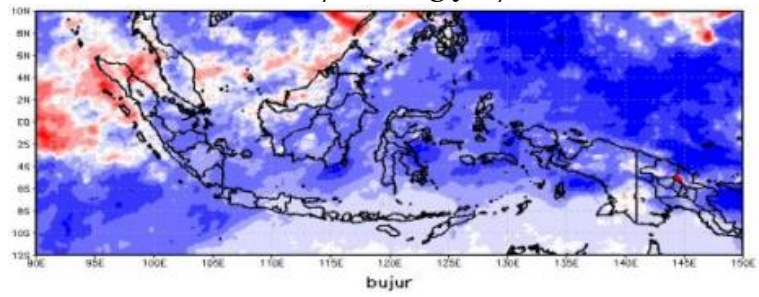

Rainfall Anomaly During September 2016

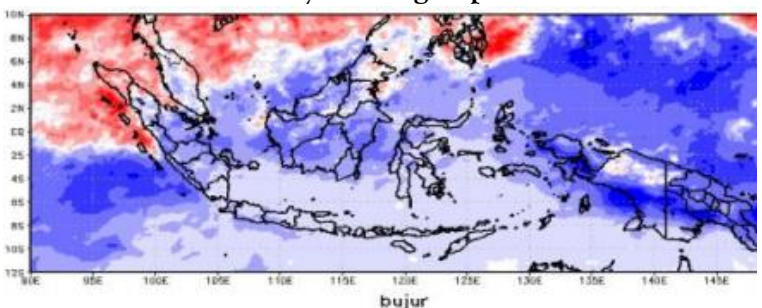

Rainfall Anomaly During November 2016

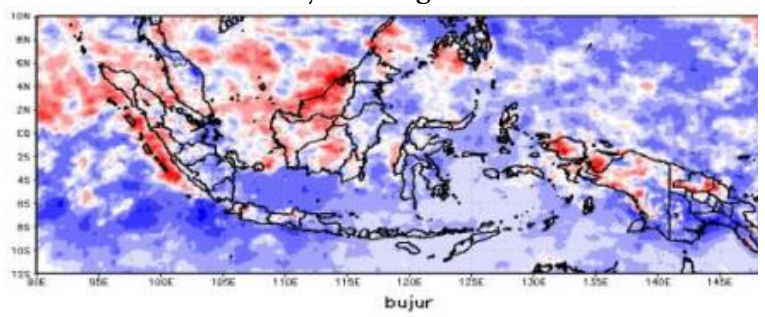

Rainfall Anomaly During April 2016

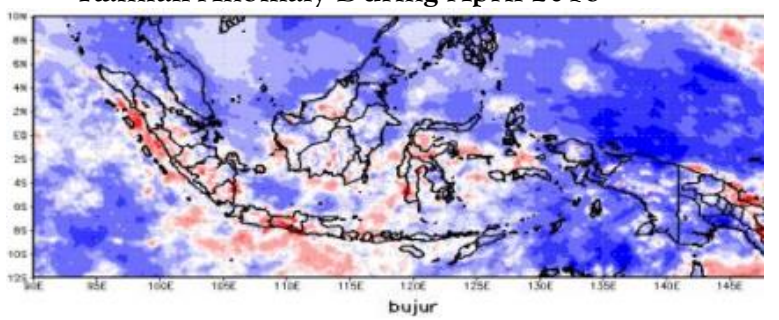

Rainfall Anomaly During June 2016

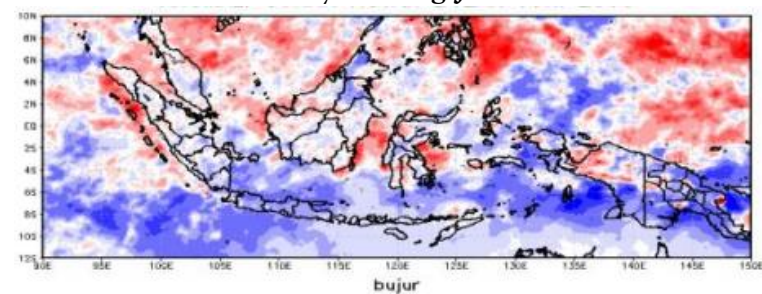

Rainfall Anomaly During August 2016

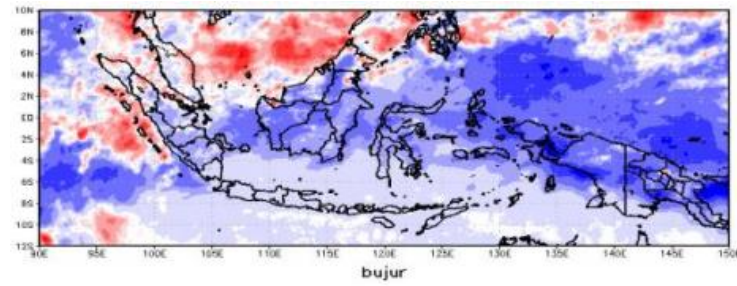

Rainfall Anomaly During October 2016

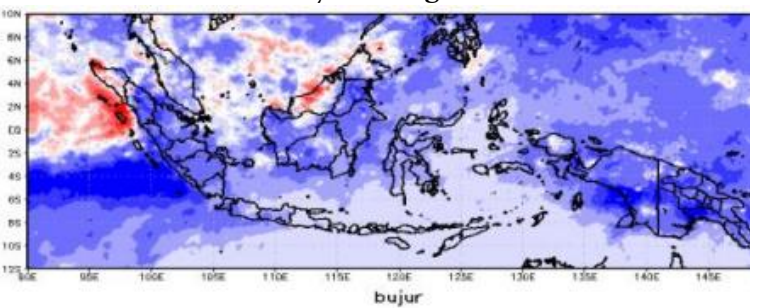

Rainfall Anomaly During December 2016
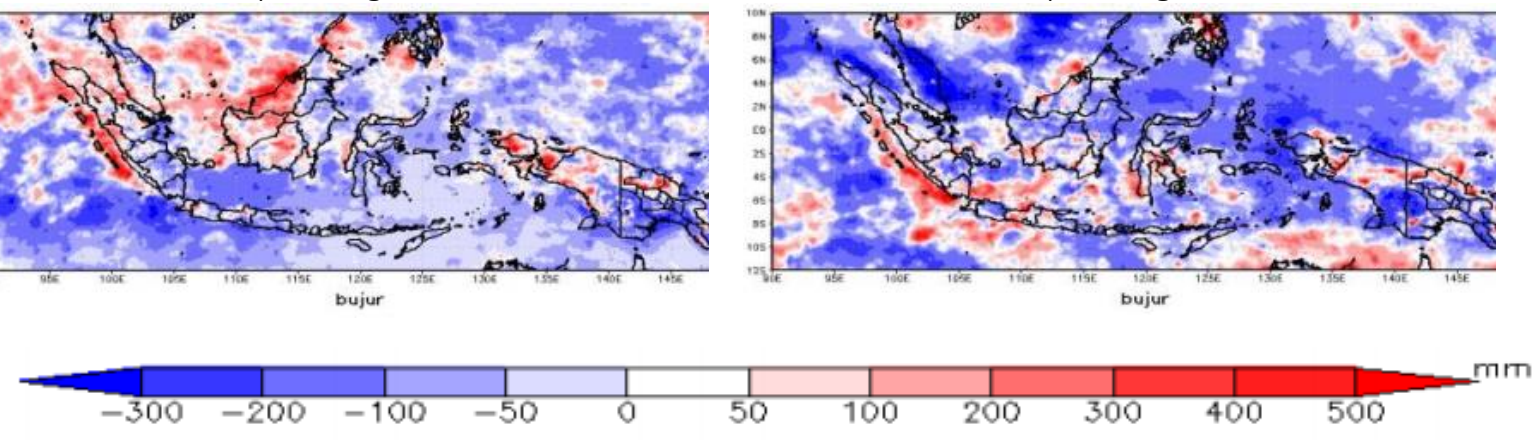

Al-Hilal: Journal of Islamic Astronomy, Vol. 3, No. 1, 2021 
Image 1: Rainfall anomaly map for Indonesia during January - December 2016

The shift of the low pressure center due to the weakening of the eastern wind in the Walker circulation affects the intensity of rainfall, especially in Indonesia. The difficulty of measuring the Qibla direction using the help of sunlight in a number of areas in Central Java is due to the increasing intensity of rainfall which causes the sun to be covered by cloudy clouds. Rainfall data used in this study is rainfall data from the Tropical Rainfall Measuring Mission (TRMM) satellite in 2016 with a spatial resolution of $0.1^{\circ} \times 0.1^{\circ}$ and a temporal resolution of one hour. Rainfall anomaly that occurs can be seen from the historical monthly average data and is presented in Figure 1. A positive anomaly indicates a monthly rainfall that is greater than the average rainfall. This can be seen in the Rainfall Anomaly from January to April 2016, the monthly rainfall in the Central Java region shows a positive anomaly.

\section{C.5. The Effect of El Nino and La Nina on The Intensity of Determining The Qibla Direction}

The role of climatology has traditionally been limited to collecting observations of the constituent elements of climate over the years to be analyzed in order to obtain an understanding of the processes that control climate. Over time, climatology has a more meaningful role in human life, namely to predict future climatic conditions ${ }^{43}$.

Climatology is divided into three parts, namely physical climatology, regional climatology and applied climatology. Physical climatology is a climatology that focuses on discussing the causes of various heat exchanges, water exchanges and air movements with respect to time and place, so that there are different climates on earth. Regional climatology is a climatology that aims to provide a

\footnotetext{
${ }^{43}$ Manik, "Klimatologi Dasar", p. 2-3.
} 
description of the world's climate which includes the nature and types of climate, while applied climatology seeks climatological relationships with other sciences ${ }^{44}$.

There are various climatological natural phenomena that occur in the earth's atmosphere. Some of these climatological phenomena are Dipole Mode and Madden Jualian Oscillation (MJO), El Nino and La Nina. In this study, the focus of the discussion is on two climatological phenomena of El Nino and La Nina in the case study area of Surakarta, Central Java, to find out how big the impact of El Nino and La Nina is in that area so that it can be concluded whether El Nino and La Nina affect the intensity of the determination qibla direction or not. Because this research focuses on discussing the climatological phenomena of El Nino and La Nina, this research is included in the discussion of Physical Climatology.

The following is the Nino 3.4 index data in the year of El Nino La Nina ${ }^{45}$ :

Table 1: Nino 3.4 Index during an El Nino Year

\begin{tabular}{lllllllllllll}
\hline YEAR & JAN & FEB & MAR & APR & MAY & JUN & JUL & AUG & SEP & OCT & NOV & DES \\
\hline 1997 & -0.55 & -0.39 & -0.32 & 0.17 & 0.56 & 1.09 & 1.44 & 1.74 & 1.97 & 2.24 & 2.32 & 2.23 \\
\hline 1998 & 2.21 & 1.89 & 1.32 & 0.86 & 0.67 & -0.15 & -0.74 & -1.12 & -1.13 & -1.27 & -1.2 & -1.52 \\
\hline 2015 & 0.51 & 0.36 & 0.42 & 0.73 & 0.87 & 0.97 & 1.2 & 1.51 & 1.75 & 2.03 & 2.36 & 2.31 \\
\hline 2016 & 2.23 & 2.01 & 1.5 & 1.11 & 0.64 & 0.05 & -0.39 & -0.63 & -0.74 & -0.87 & -0.93 & -0.72 \\
\hline
\end{tabular}

Table 2: Nino 3.4 Index during an La Nina Year

\begin{tabular}{lllllllllllll}
\hline YEAR & JAN & FEB & MAR & APR & MAY & JUN & JUL & AUG & SEP & OCT & NOV & DES \\
\hline 1998 & 2.21 & 1.89 & 1.32 & 0.86 & 0.67 & -0.15 & -0.74 & -1.12 & -1.13 & -1.27 & -1.2 & -1.52 \\
\hline 1999 & -1.58 & -1.24 & -0.84 & -0.87 & -0.9 & -1.02 & -0.95 & -1.1 & -0.99 & -1.13 & -1.43 & -1.6 \\
\hline 2010 & 1.26 & 1.11 & 0.88 & 0.51 & 0.02 & -0.44 & -0.79 & -1.16 & -1.41 & -1.36 & -1.31 & -1.34 \\
\hline 2011 & -1.46 & -1.05 & -0.76 & -0.55 & -0.34 & -0.13 & -0.2 & -0.52 & -0.79 & -0.86 & -0.91 & -0.85 \\
\hline
\end{tabular}

Based on the two tables above, it can be seen the year and month of El Nino and La Nina. So that it can be seen the intensity of determining the direction of the Qibla in the year of El Nino and La Nina. The next discussion is a comparison of climate elements in the year of El Nino and La Nina in Surakarta.

\footnotetext{
${ }^{44}$ Bayong Tjasyono, "Klimatologi Umum", (Bandung: Institut Teknologi Bandung Press, 1999), p.3-4.

${ }^{45}$ Class 1 Semarang Climatology Office, "Indeks Nino 3.4 Saat Tahun Terjadinya El Nino Dan La Nina," n.d.
} 
Wet month is a month with rainfall intensity of $200 \mathrm{~mm}$ and dry month is $<100 \mathrm{~mm}^{46}$. During the El Nino year, dry months occur on 22 June - 1 August, with only $1.75 \mathrm{~mm}$ of rainfall. Meanwhile, on 2 August - 24 August and 25 August - 17 September there was no rain at all or the rainfall was zero. On 18 September - 12 October, the rainfall was still very low, only $13 \mathrm{~mm}$.

The wet months occurred on 9 November - 11 May with rainfall intensity between $225 \mathrm{~mm}$ to $403.3 \mathrm{~mm}$, while on 13 October - 8 November and 12 May 21 June the rainfall was moderate, that was $148 \mathrm{~mm}$ and $106 \mathrm{~mm}$.

By looking at the intensity of rainfall during the El Nino year, it can be seen that the good months for determining the direction of the Qibla during the year of El Nino are only during 22 June - 1 August, with a rainfall intensity of 1.75 $\mathrm{mm}$ and a long sun exposure of 92.7\%. During 2 August - 24 August, the observer does not need to worry about the occurrence of rain which can interfere with the process of determining the direction of the Qibla because during this month there was no rain falling or the intensity of rainfall was zero and the length of sun exposure was quite a lot, that is $92.2 \%$. Likewise, during 25 August - 17 September, there was no rain and the maximum sun exposure was $97.7 \%$. During 18 September - 12 October, it was also a good month and it was considered safe to determine the direction of the Qibla because during this month the rainfall was still very low, only $13 \mathrm{~mm}$ with a long sun exposure of $95.3 \%$.

The annual Rashdul Qibla which occurs on 15 or 16 July is likely to be carried out safely. However, the annual Rashdul Qibla that occurs on 27 or 28 May is likely to be a little disturbed by the obstacles to rainfall, although it is not very high. On 27 and 28 May, the rainfall reached $106 \mathrm{~mm}$ and the length of sunshine was $86 \%$.

During the year of La Nina, the rain falls throughout the year although with different intensities. Wet months $(<100 \mathrm{~mm})$ during the year of La Nina occurred on 12 May - 21 June (72.5 mm), 22 June - 1 August (53.5 mm), 2 August - 24 August (49, $33 \mathrm{~mm})$ and on August 25 - September $17(67.17 \mathrm{~mm})$.

${ }^{46}$ Tjasyono, Klimatologi Umum, p. 155. 
So that the determination of the direction of the Qibla using either the theodolite or the sun even though it is done in dry months, it is still possible to have obstacles caused by cloudy or even rain. However, the annual Rashdul Qibla that occurred on 27 or 28 May $(72.5 \mathrm{~mm})$ and 15 or 16 July $(53.5 \mathrm{~mm})$ coincided in the dry months.

\section{Conclusion}

The El Nino phenomenon does not really affect the intensity of determining the direction of the Qibla because during the year of El Nino there is a dry month which is safe to determine the direction of the Qibla, even there are four months where there is no rain at all. In contrast to El Nino, the La Nina phenomenon has quite an effect on the intensity of determining the Qibla direction because during La Nina year, rain occurs throughout the year, even though there are four dry months (rainfall intensity $<100 \mathrm{~mm}$ ), the implementation of determining the Qibla direction is still likely to meet obstacles due to cloudiness or even rain.

\section{References}

Abu al-Husain Muslim ibn Hajjaj ibn Muslim al-Qusyairi al-Naisabury. Shahih Muslim. Beirut: Dar al-Kutub al-'Ilmiyyah, n.d.

B. Tjasyono, A. Lubis, I. Juaeni, Ruminta, S.W.B. Harijono, "Dampak Variasi Temperatur Samudera Pasifik Dan Hindia Ekuatorial Terhadap Curah Hujan Di Indonesia" Jurnal Sains Dirgantara 5, no. 2 (2008).

Bungin, Burhan, "Metodologi Penelitian Kuantitatif, Komunikasi, Ekonomi Dan Kebijakan Publik Serta Ilmu - Ilmu Sosial Lainnya", Jakarta: Kencana, 2005.

Class I Semarang Climatology Office, "Indeks Nino 3.4 Saat Tahun Terjadinya El Nino dan La Nina”, n.d.

Dewi, Ardila Yananto dan Saraswati, "Analisis Kejadian El Nino Tahun 2015 dan Pengaruhnya Terhadap Peningkatan Titik Api Di Wilayah Sumatera Dan Kalimantan” Jurnal Sains \& Teknologi Modifikasi Cuaca 17, no. 1 (2016). pintarbiologi.com. "El Nino: Pengertian, Dampak, Dan Proses Terjadinya” n.d. 
National Oceanic and Atmospheric Administration, "Equatorial Pacific Sea Surface Temperatures" n.d.

Faizah, Isniyatin. "Studi Analisis Penanggalan Jawa Pranata Mangsa Dalam Perspektif Astronomi" IAIN Walisongo Semarang, 2013.

ilmugeografi.com, "Fenomena Alam Proses Terjadinya El Nino Dan La Nina" n.d.

Hambali, Slamet. Metode Pengukuran Arah Kiblat Yang Dikembangkan Di Pon-Pes Al-Hikmah II Benda Sirampak Kabupaten Brebes. Semarang: IAIN Walisongo, 2010.

Holland, Roy. Kamus Matematika ( A Dictionary of Mathematics), translated by Naipospos Hutauruk, Jakarta: Erlangga, 1999.

Immanuel Ryadi, Gabriel Yedaya, Abdi Sukmono, and Bandi Sasmito, "Pengaruh Fenomena El Nino dan La Nina pada Persebaran Curah Hujan dan Tingkat Kekeringan Lahan di Pulau Bali”, Jurnal Geodesi Undip 8 (October 7, 2019).

https://ejournal3.undip.ac.id/index.php/geodesi/article/view/25143.

Izzuddin, Ahmad, "Kajian Terhadap Metode-Metode Penentuan Arah Kiblat Dan Akurasinya", Jakarta: Kementerian Agama RI, Direktorat Jenderal Pendidikan Islam, Direktorat Pendidikan Tinggi Islam, 2012.

J., James A. Black \& Dean, and Champion, "Metode Dan Masalah Penelitian Sosial", translated by Koswara, et.al, Bandung: Refika Aditama, 2009.

Jumin, Hasan Basri, "Agroekologi: Suatu Pendekatan Fsisiologis", Jakarta: Raja Grafindo Persada, 2002.

Kadir, A, "Quantum Ta'lim Hisab-Rukyat: Cara Cepat Pintar Kalkulasi Arah Kiblat Syar'i, Waktu-Waktu Shalat Abadi, Plus Awal Bulan $\mathcal{E}$ Gerhana Sistem 45 Menit", Semarang: Fatawa Publishing, 2014.

Manik, Tumiar Katarina, "Klimatologi Dasar", Yogyakarta: Graha Ilmu, 2014.

Meteorological, Climatological, and Geophysical Agency: BMKG, "2015 Dry Season Forecast in Indonesia" Jakarta, 2015.

Ministry of Religious Affairs of The Republic of Indonesia, "Al-Quran dan Terjemahnya" Jakarta: CV. Darus Sunnah, 2007.

Mustafa, Ahsin Dinal, “Qibla Direction Trough Ulama's Fatwa: Comparative Study between Qibla Direction Fatwa of Indonesian Ulama Council and Dar Al Ifta Al Misriyyah" Al-Hilal: 
Journal of Islamic Astronomy 1 (2019).

Nabilah, Farras, Yudo Prasetyo, and Abdi Sukmono, "Analisis Pengaruh Fenomena El Nino dan La Nina terhadap Curah Hujan Tahun 1998 - 2016 Menggunakan Indikator Oni (Oceanic Nino Index) (Studi Kasus : Provinsi Jawa Barat)", Jurnal Geodesi Undip 6 (November 15, 2017). https://ejournal3.undip.ac.id/index.php/geodesi/article/view/18170.

Ni'am, M. Ihtirozun, "Al-Murobba': Inovasi Alat Falak Multifungsi", Semarang: Mutiara Aksara, 2020.

Ni'am, M. Ihtirozun, Nizma Nur Rahmi, and Fiki Burhanuddin, "Qibla Direction with The Constellation (Study on Determination of Qibla Direction with Gubug Penceng)" Al-Hilal: Journal of Islamic Astronomy 2 (2020).

Ni'am, M Ihtirozun. "Tsuroyya's Star as A Sign of Pandemic's End (Critical Study of The End of A Pandemic From Hadith And Astronomical Perspective)", ELFALAKY 4, no. 2 (2020).

Null, Jan, "El Nino and La Nina Years and Intensities", n.d.

Prasetya, R, "Analisis Curah Hujan Akibat Siklon Tropis Nangka, Parma Dan Nida Di Sulawesi Utara", Universitas Sam Ratulangi Manado, 2011.

Sibarani, Ardila Yananto dan Rini Mariana, "Analisis Kejadian El Nino dan Pengaruhnya terhadap Intensitas Curah Hujan Di Wilayah Jabodetabek (Studi Kasus: Periode Puncak Musim Hujan Tahun 2015/2016).” Jurnal Sains \& Teknologi Modifikasi Cuaca 17, no. 2 (2016).

Sinon, Iriwi L.S. "Identifikasi Pengaruh El Nino dan La Nina Terhadap Variasi Curah Hujan Tahunan Di Kabupaten Biak Numfor Provinsi Papua”, presented in Seminar Nasional Pendidikan, Banjarmasin, 2018.

Sodiq, Moch, "Pemanasan Global: Dampak Terhadap Kehidupan Manusia Dan Upaya Penanggulangannya", Yogyakarta: Graha Ilmu, 2013.

Sosrodihardjo, Bungaran Antonius Simanjuntak dan Soedjito, "Metode Penelitian Sosial", Jakarta: Yayasan Pustaka Obor Indonesia, 2009.

Tjasyono, Bayong, "Klimatologi Umum", Bandung: Institut Teknologi Bandung Press, 1999. 
